\title{
Invited review: Dairy proteins and bioactive peptides: Modeling digestion and the intestinal barrier
}

\author{
Carlotta Giromini, ${ }^{*}$ Federica Cheli, Raffaella Rebucci, and Antonella Baldi \\ Department of Health, Animal Science and Food Safety, Università degli Studi di Milano, Milan, Italy 20134
}

\section{ABSTRACT}

Dairy products are one of the most important sources of biologically active proteins and peptides. The healthpromoting functions of these peptides are related to their primary structure, which depends on the parent protein composition. A crucial issue in this field is the demonstration of a cause-effect relationship from the ingested protein form to the bioactive form in vivo. Intervention studies represent the gold standard in nutritional research; however, attention has increasingly been focused on the development of sophisticated in vitro models of digestion to elucidate the mechanism of action of dairy nutrients in a mechanistic way and significantly reduce the number of in vivo trials. On the other hand, the epithelial intestinal barrier is the first gate that actively interacts with digestion metabolites, making the intestinal cells the first target tissue of dairy nutrients and respective metabolites. An evolution of the in vitro digestion approach in the study of dairy proteins and derived bioactive compounds is the setup of combined in vitro digestion and cell culture models taking into consideration the endpoint to measure the target organism (e.g., animal, human) and the key concepts of bioaccessibility, bioavailability, and bioactivity. This review discusses the relevance and challenges of modeling digestion and the intestinal barrier, focusing on the implications for the modeling of dairy protein digestion for bioactivity evaluation.

Key words: dairy protein, bioactive peptide, in vitro digestion, intestinal cell

\section{INTRODUCTION}

Dairy products are one of the most important sources of high-value proteins and bioactive peptides. Beyond their well-known nutritional values, they exhibit an extensive range of physiological effects that promote general health through their beneficial effects on spe-

Received June 5, 2018.

Accepted October 11, 2018.

*Corresponding author: carlotta.giromini@unimi.it cific organs and tissues (Meisel and FitzGerald, 2003; Martínez-Maqueda et al., 2012a). The nutraceutical industry has developed a strong interest in studying and discovering bioactive molecules from complex food mixtures, such as dairy products, for the production of health-promoting functional foods. The most important health benefit of dairy proteins is obtained following gastrointestinal digestion and peptide release (PetratMelin et al., 2015; Giromini et al., 2017). A peptidome study performed on human jejunal effluents after ingestion of milk proteins identified protein domains resistant to gastrointestinal digestion (Sanchón et al., 2018). Some of these resistant peptide fragments correspond to previously described sequences that might exert their physiological function by directly interacting with the intestinal epithelium or by being absorbed into the bloodstream and distributed throughout the body, where they elicit unique functions (Shimizu, 2004). To evaluate the health-promoting role of these bioactive peptides, attention has increasingly been focused on in vitro digestion models. Although intervention studies represent the gold standard in nutritional research, in vitro methods for the simulation of the gastrointestinal protein digestion process are currently widely used in food and nutraceutical research (Minekus et al., 2014, Guerra et al., 2012). These methods are rapid, less expensive, and involve fewer ethical restrictions compared with in vivo trials; moreover, they can elucidate the mode of action of nutrients in a mechanistic way with a significant reduction of the use of laboratory animals, following the principle of replacement, reduction, and refinement of animal studies. Moreover, the attempt of modeling milk proteins digestion in vitro can determine the bioaccessibility of dairy peptides, the effect of their chemical form, and the synergistic effect of all the dairy peptides produced during the digestion process (Guerra et al., 2012). The epithelial barrier is the first gate, which actively interacts with digestion components, making the intestinal cells one of the first target tissues of dairy proteins and derived peptides. Intestinal cell-based models have been used in food and feed research as predictive tools to study the absorption and the bioactivity of dairy proteins and derived pep- 
tides (Contreras et al., 2011). The setup of combined in vitro digestion and cell culture models represents an evolution of the in vitro digestion approach currently applied to study dairy nutrients and derived peptides bioactivity. This review discusses the relevance and challenges in modeling digestion and intestinal barrier function, focusing on the implications for modeling of dairy protein digestion for bioactivity evaluation.

\section{BIOACTIVE COMPOUNDS OF MILK AND DAIRY PRODUCTS}

Milk and dairy products represent complete food sources of macro- and micronutrients that also impart a wide range of health benefits to the consumer due to the amount of biologically active molecules they possess (Hill and Newburg, 2015). Among dairy products, cheese whey is a sustainable and high-value by-product of the dairy processing industry (Smithers, 2015), characterized by a high amount of proteins and oligosaccharides with an elevated potential for the production of functional foods. The bioactivity of dairy compounds is largely derived from high-quality proteins and peptides (Baldi et al., 2005; Politis and Chronopoulou, 2008; Fox et al., 2015) and partially derived from milk lipids (Haug et al., 2007; Baldi and Pinotti, 2008; Rosetta and Baldi, 2008), oligosaccharides (Boudry et al., 2017; Douëllou et al., 2017), and micronutrients such as calcium, phosphorus, sodium, and vitamins (Caroli et al., 2011). Among the wide range of dairy bioactive molecules, proteins and peptides have been largely investigated (Martínez-Maqueda et al., 2012b; Petrat-Melin et al., 2015; Giromini et al., 2017) and their bioactivity has been extensively reviewed in recent years (Purup and Nielsen, 2012; Holt et al., 2013; Sultan et al., 2018; Table 1).

In spite of the vast number of studies focused on the evaluation of milk proteins and peptide functionality, an imbalance exists in the literature, as most of this attention has focused on the effect of specific peptides (e.g., $\beta$-casomorphin, lactoferricin) with a clear evidence gap regarding the synergistic effect of the peptide milieu from casein and whey proteins (Fekete et al., 2016a; Giromini et al., 2017), particularly at the gastrointestinal level. Nevertheless, in vivo studies investigating the bioactive properties of dairy proteins are still rare and sometimes produce controversial results (Egger and Ménard, 2017). Based on this information, studying the effects of milk and dairy bioactive peptides as a whole and considering the natural co-occurrence of bioactive peptide in dairy products is of paramount importance.

\section{IN VITRO MODELS OF DAIRY PROTEIN DIGESTION}

The study of dairy protein digestion represents a prerequisite for the determination of the physiological properties of encrypted peptides. When in vitro models mimicking the physiology of protein digestion are designed, the key concepts of bioaccessibility, bioavailability, and bioactivity must be studied. The fraction of ingested protein that is effectively released from the food matrix and available for intestinal absorption is defined as bioaccessible, whereas bioavailability is defined as the quantity of ingested protein that becomes available for utilization at the blood vessel level (Parada and Aguilera, 2007; Figure 1).

The bioaccessibility of a protein is a key parameter for the determination of its bioavailability. Thus, bioavailability is the result of 3 main steps: protein digestibility or solubility in the gastrointestinal tract, absorption by the intestinal epithelial cells, and tissue distribution. Bioavailability is usually determined by in vivo assays, which consider individual variability, physiological state, dose, and the co-presence of other food components. Thus, although bioavailability and bioaccessibility are often used indistinctly, they are not equivalent; it must be clarified that bioavailability includes the concept of bioactivity (Etcheverry et al., 2012). Bioactivity represents all events linked to how the bioactive compound reaches the target tissue, interacts with biomolecules, and how it is metabolized and transformed to induce a physiologic response. The

Table 1. Selection of comprehensive reviews on dairy bioactive proteins and peptides for further reading

\begin{tabular}{|c|c|c|}
\hline Target district & Bioactive effect & References \\
\hline Cardiovascular system & $\begin{array}{l}\text { Antihypertensive, blood pressure } \\
\text { regulation }\end{array}$ & $\begin{array}{l}\text { Aluko, 2015; Fekete et al., 2013, 2015; Beltrán-Barrientos et al., 2016; } \\
\text { Bhat et al., 2017; Egger and Ménard, 2017; Miralles et al., 2018a }\end{array}$ \\
\hline Immune system & Immunomodulatory, cytomodulatory & $\begin{array}{l}\text { Santiago-López et al., 2016; Egger and Ménard, 2017; Cicero et al., } \\
\text { 2017; Miralles et al., 2018a }\end{array}$ \\
\hline Nervous system & Opioid effect, cognitive function & Visioli and Strata, 2014; Nongonierma and FitzGerald, 2015, 2016 \\
\hline Diverse & Antioxidant, mineral binding & Nongonierma and FitzGerald, 2015; Sultan et al., 2018 \\
\hline
\end{tabular}




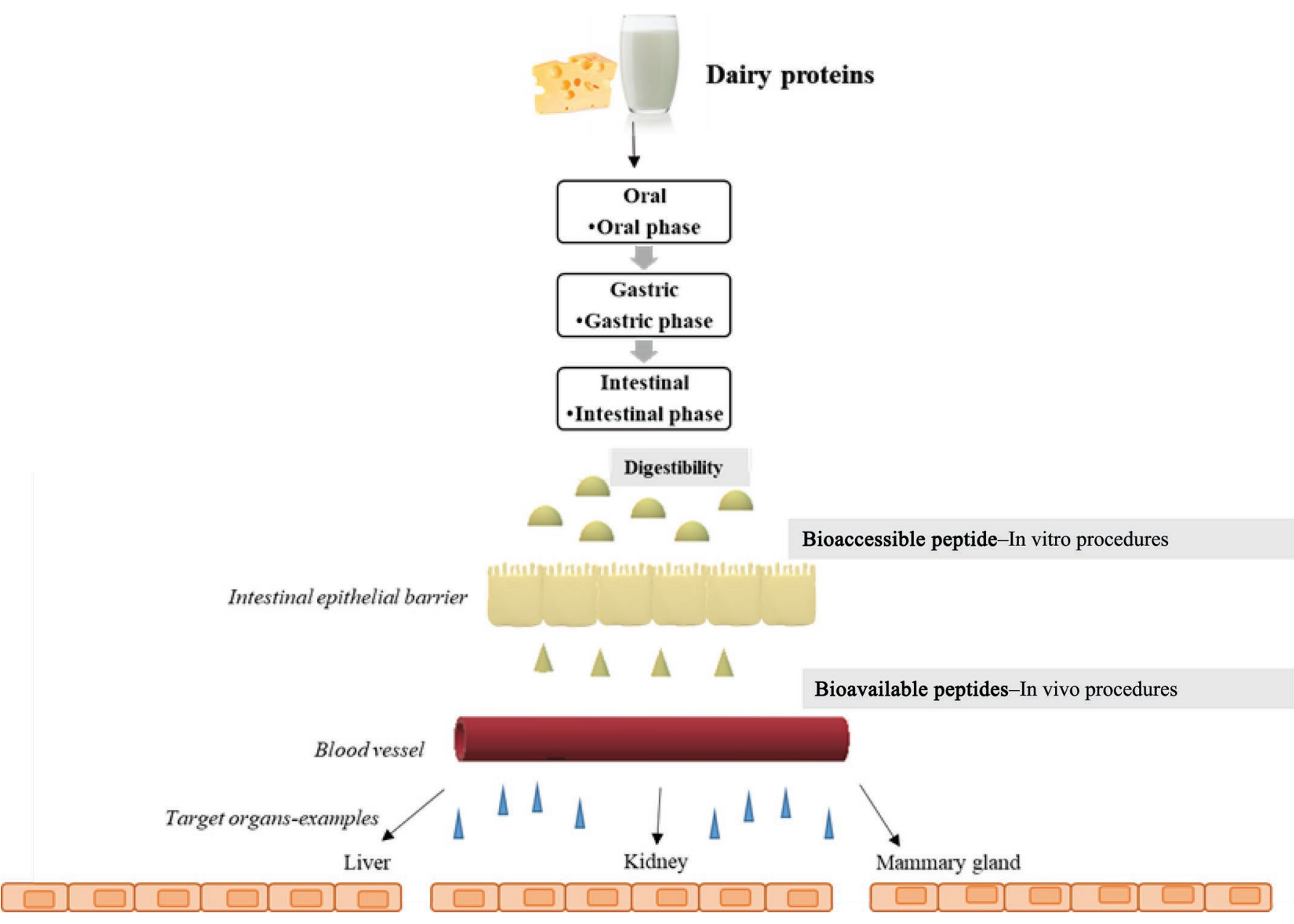

Figure 1. Bioaccessibility and bioavailability concepts applied to dairy proteins (adapted with permission from Guerra et al., 2012).

bioavailability and bioactivity of a peptide are dependent on gastrointestinal parameters, food processing, and food matrix complexity, which, altogether, affect the efficiency of the digestion and absorption processes. Claims of what a dairy food can do (health properties or disease reduction) are based on bioactivity studies. The development and validation of in vitro models for bioaccessibility, bioavailability, and bioactivity studies are a difficult task and should consider the complexity of the gastrointestinal tract, gut ecosystem, and the physiology of target subject.

In vivo protein digestion begins when food proteins reach the stomach, and digestion is assisted by the highly acidic gastric environment. The gastric digestion conditions have a $\mathrm{pH}$ ranging from 1 to 5 and a transit time of $30 \mathrm{~min}$ to $3 \mathrm{~h}$. In the stomach, the gastric juice primarily promotes protein digestion. This acidic environment in the stomach causes the unfolding of proteins, and the gastric enzymes are thus granted easier access to the protein structures to cleave them into smaller pieces. At the gastric level, casein proteins are extensively degraded by pepsin hydrolysis in both adults and infants (Boland et al., 2014). The globular structure of whey proteins renders them more resistant to gastrointestinal hydrolysis. In particular, $\beta$-LG can interact with phosphatidylcholine of the gastric mucosa while not being affected by gastric digestion, which, in turn, protects the protein from duodenal digestion. Lactoferrin, although relatively resistant to digestion by proteases in the gastrointestinal tract, can be actively hydrolyzed during gastric digestion into the most potent bioactive peptide, lactoferricin (Baldi et al., 2005; Furlund et al., 2013). Diverse results have been reported on the digestibility of the second major whey protein, $\alpha$-LA (Inglingstad et al., 2010; Nik et al., 2010). Even though casein proteins have a structure that makes them sensitive to enzymatic hydrolysis, they are considered slow proteins due to the longer retention in the stomach compared with whey protein (fast protein). The longer stomach retention of caseins 
lead to a longer persistence of casein-derived AA in plasma compared with whey-derived AA (Boirie et al., 1997).

Gastric-protein digestion in the small intestine, the longest section (Guerra et al., 2012) of the digestive tube, representing the first highly selective communication barrier between the gastrointestinal environment and the metabolic organs. Trypsin and additional enzymes, such as carboxypeptidase and aminopeptidase, are present in the small intestine and contribute to the intestinal hydrolysis of proteins. Di- and tripeptides of the digestate can be transported by specific transporters or hydrolyzed into AA at the intestinal epithelial cell level and subsequently absorbed into the bloodstream and distributed throughout the body, where they elicit unique functions (Shimizu, 2004). Unabsorbed polypeptides reach the large intestine (cecum, colon, and rectum) where fermentation and water reabsorption occur with a transit time over $12 \mathrm{~h}$ in adults (Guerra et al., 2012).

\section{Static Models to Study Dairy Bioactives}

The design of a model has to take into account several aspects related to the food matrix, composition, and human and animal physiology. Static and dynamic models with single or multicompartmental systems have been developed to simulate the physiological process of digestion. Static models consist of a 2- or 3 -step procedure simulating the digestive processes in the mouth, stomach, and small intestine, with the addition of simulated gastric and intestinal juices and incubation at $37^{\circ} \mathrm{C}$ for a time relevant to the specific compartment (Minekus et al., 2014). Static models are relatively cheap and the most widespread among researchers studying digestion and the bioactivity of various nutrients, including milk and dairy proteins. These models reproduce the digestion phases at a fixed temperature and $\mathrm{pH}$. The oral, gastric, and intestinal phases are simulated in the same system using single enzymes (pepsin), enzyme combination (pancreatic and liver enzymes), or a defined medium that reproduces gastric or intestinal juices. Some of the static models use mechanical force to simulate peristaltic movements and may include mechanisms for undigested food or end-product removal (Guerra et al., 2012). By 2014, hundreds of static systems had been developed and used to study digestion, making the standardization of the results and their reproducibility a difficult task. The first attempt to validate an international consensus protocol was performed by Minekus et al. (2014). Those authors developed a harmonized protocol, improving health properties of food by sharing our knowledge on the digestive process (INFOGEST), to simulate the in vitro digestion of food to increase the reproducibility of results among different laboratories and countries (Figure 2). The INFOGEST protocol was set up and validated on milk powder samples, and the bioaccessibility of milk proteins has been used to assess the suitability of the protocol.

Compared with other in-house methods, the INFOGEST protocol revealed a high hydrolysis potential and a more homogeneous protein pattern in the digestion samples with no intact proteins detectable (Bohn et al., 2017). In general, the widespread application of the INFOGEST protocol is currently improving the com-

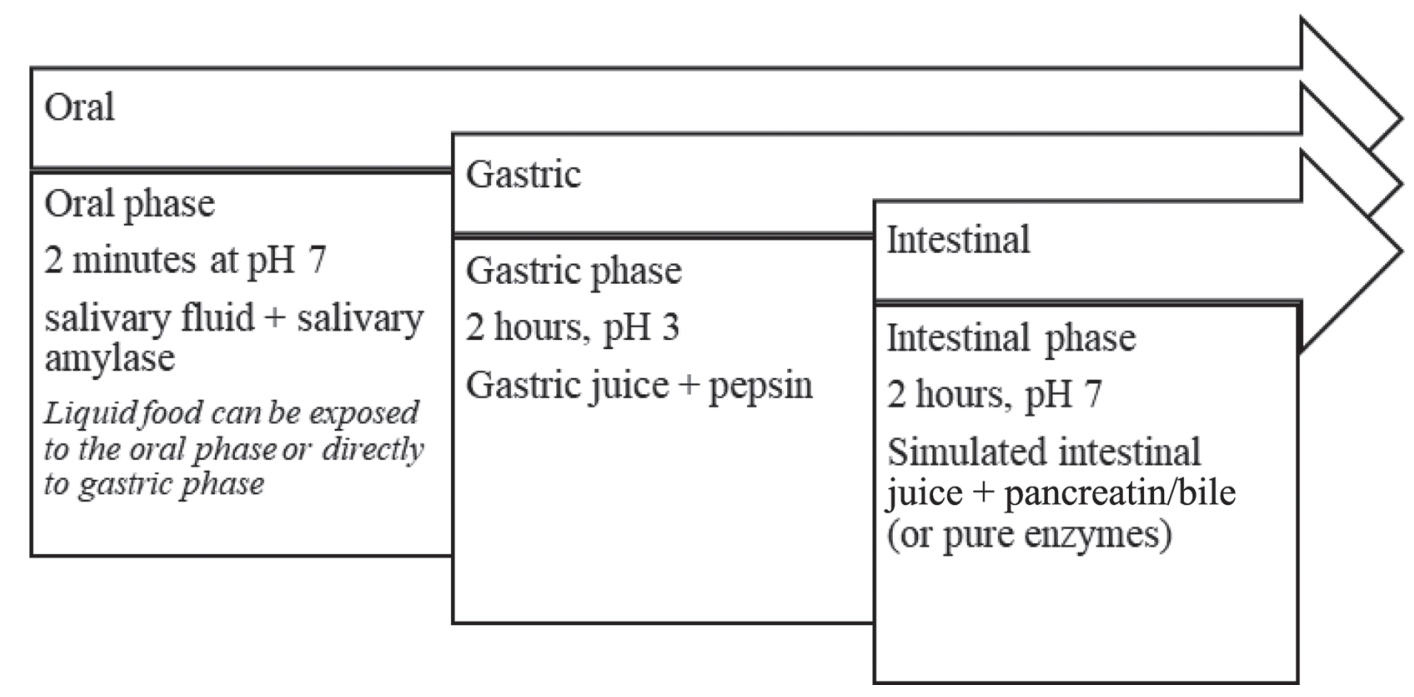

Figure 2. The static in vitro digestion protocol developed in the frame of the COST Action INFOGEST (Minekus et al., 2014). The protocol allows the standardization of the oral, gastric, and intestinal digestion conditions in vitro. 
parability of the results among different laboratories studying milk protein hydrolysis or bioactivity. Egger et al. (2016) studied the fate of casein and whey proteins after ingestion using the INFOGEST protocol and found that casein is mainly hydrolyzed after the pepsin phase, whereas whey proteins, such as $\beta-\mathrm{LG}$, were resistant to pepsin attack. Furthermore, comparison of the INFOGEST protocol with in vivo models was first performed in a pig model and, later, in humans. The same sample of milk powder used to validate the INFOGEST was tested in a swine trial, showing that the in vitro gastric and intestinal phases reflected in vivo milk protein hydrolysis and bioaccessibility (Bohn et al., 2017). In a recent study, Sanchón et al. (2018) performed a comparison of the INFOGEST protocol with human digestion data and found that it resembled the in vivo intestinal digestion and peptide release. After the harmonization of the static digestion protocol, several studies have been performed using the INFOGEST protocol to study the bioaccessibility and the bioactivity of milk and dairy proteins and peptides. The digestion, hydrolysis, and peptide profile from casein was investigated by Asledottir et al. $(2017,2018)$ in digestates from casein and from ex vivo gastrointestinal digestion. In our research group, we digested a selection of whey, casein, and plant proteins in vitro and found an increase in angiotensin I-converting enzyme (ACE) inhibitory activity after in vitro dairy protein digestion (Fekete et al., 2016a; Giromini et al., 2017). The bioactivity detected in vitro was substantiated by 2 human intervention studies where casein and whey protein were administered in powder form orally to human volunteers (Fekete et al. 2016a, 2018). We found that whey and casein protein administration resulted in a lower blood pressure and improved cardiovascular biomarkers in adults with prehypertension and mild hypertension. Furthermore, De Noni et al. (2015) and Cattaneo et al. (2017) studied the effect of the INFOGEST protocol on Grana Padano cheese digesta and the casein profile. The INFOGEST protocol was also used to study the effect of a lipoproteinic matrix structure on the digestion kinetics of whey proteins (Mat et al., 2016). This evidence demonstrates the suitability of the protocol to study milk protein digestion with a high predictive power on the released peptides and bioaccessibility. In turn, this can be used to investigate the associated bioactivity. In general, static models are particularly useful for the standardization of results, providing an enormous boost to the practical and economic potential of bioactivity measurements. Nevertheless, despite their potential and broad applicability to study bioaccessibility (and bioactivity), none of the static models reproduce the dynamic environment of the intestine.

\section{Dynamic Models to Study Dairy Bioactives}

Digestion is a dynamic process. Among the dynamic models available, either mono- or multicompartmental systems have been used for the study of dairy protein digestion. In the dynamic models, the exact conditions within the different compartments change over time to simulate the in vivo digestion processes. Dynamic digestion models account for the different digestive secretions, which are added to the compartments of the model at specific time points. This addition can either follow a stable secretion rate (as for the simulated gastric juice in the human gastric simulator), it can follow a preprogrammed pattern (allowing the rate to change over time; e.g., in the TIM-1 model), or it can be programmed to change in response to other parameters, such as the volume of the model (e.g., gastric secretion in the dynamic gastric model; Thuenemann et al., 2015). Concerning dairy protein digestion evaluation, dynamic models have only been applied in few cases. A summary of the main application of dynamic models to study dairy protein digestion and or bioactivity is reported in Table 2.

Specific dynamic digestion models tailored for specific human populations have also been studied (ShaniLevi et al., 2017). The gastrointestinal system and the digestion process of an adult differs from that of a neonate or a small child, making the standardization of the digestion protocols difficult to accomplish. These differences need to be considered when choosing or developing a digestion protocol. Most of the established in vitro models have been designed to simulate the specific processes taking place within an adult human. The digestion process differs in children, seniors, and pathological patients (e.g., inflammatory bowel disease); therefore, the in vitro models developed to simulate the digestion in adults will not accurately reflect processes occurring in those individuals (Kamstrup et al., 2017). Customized models may represent new tools to accurately evaluate the bioaccessibility of tailored and personalized foods for a specific stratum of the human population, such as infants, the elderly, and patients with gastrointestinal disorders. In the near future, dynamic digestion systems will likely become unavoidable for understanding the mechanisms of digestion and absorption, especially because of the increased ethical and economic constraints of in vivo trials. Therefore, the harmonization of a dynamic digestion protocol represents one future goal to achieve in nutritional research.

Egger et al. (2017) took a step forward in the validation of a dynamic model. In their study, dairy protein was digested with the INFOGEST protocol and the 


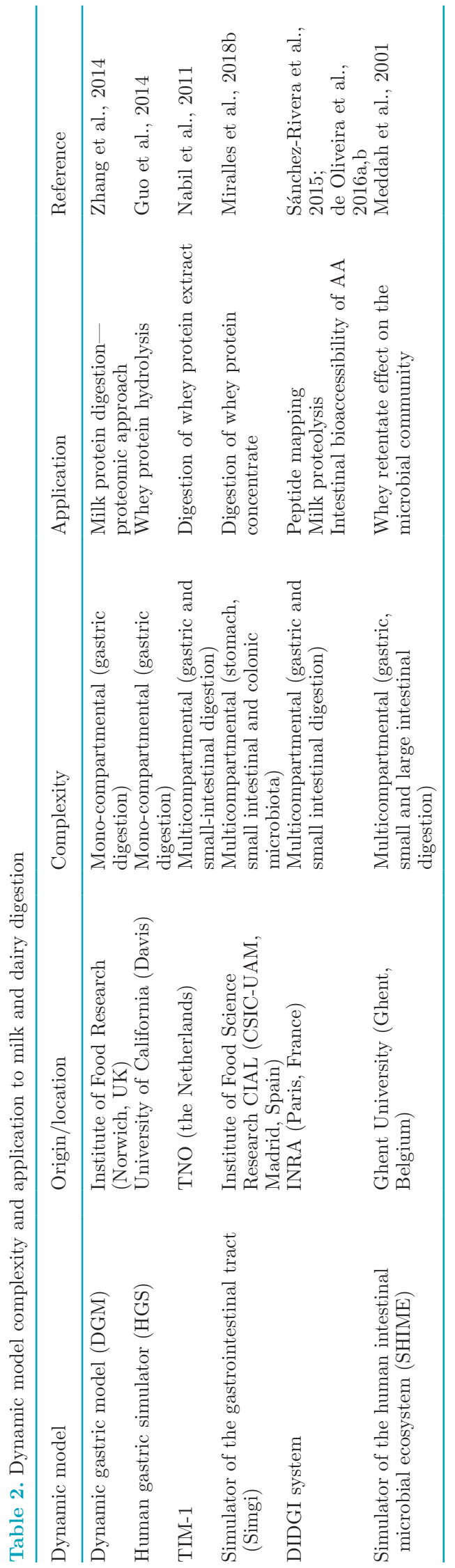

dynamic protocol DIDGI (Ménard et al., 2015). The hydrolysis of proteins was compared between the 2 systems, as well as to in vivo porcine digestion. The gastric and intestinal endpoints of both in vitro systems showed good reproducibility compared with porcine in vivo digestion. In particular, during the gastric phase, the kinetic of protein hydrolysis in DIDGI showed a dynamic evolution and was closer to the in vivo situation.

Generally, dynamic models to study dairy protein digestion and the bioaccessibility of AA are capable of mimicking the gastric digestion of milk proteins with a high predictive power (Miralles et al., 2018b). However, to date, the lack of standardization and the high cost of the dynamic models limits their widespread application.

\section{IN VITRO MODELS OF THE INTESTINAL BARRIER}

The intestine is a composite environment responsible for processing and absorbing nutrients also serving as a selective epithelial barrier to protect against pathogens entering with food (Robert et al., 2017). The intestinal epithelial barrier consists of different types of cells, including the absorptive enterocytes and other specialized intestinal epithelial cells (IEC; Peterson and Artis, 2014; Table 3). These cells cooperatively work together to maintain the dynamic barrier between the luminal and outer environments to avoid the hazards associated with the intrusion of undesired substances, such as pathogenic or opportunistic bacteria, viruses, food derived antinutritional compounds, and mycotoxins.

In addition to these major cell types, microfold, cup, tuft, and M cells can also be found in the gastrointestinal epithelium (Gerbe et al., 2012). Enterocytes and colonocytes are the main representative cells in the small and large intestine, respectively, as they comprise $80 \%$ of the IEC (Goto and Kiyono, 2012). Enterocytes and colonocytes are specialized in the absorption of nutrients (e.g., peptides) in the small and large intestines, respectively. Peptide absorption occurs through different pathways, including paracellular diffusion via tight junction, passive diffusion via enterocytes or endocytosis, and carrier-mediated diffusion via the PepT1 $\mathrm{H}^{+}$/peptide cotransporter (PepT1). Wang and Li (2017) reported that peptides transported by PepT1 showed higher bioavailability than peptides transported through the paracellular route. An alternative absorption pathway, suggested by Martínez-Maqueda et al. (2012a), involves the activity of small peptides on opioid receptors present in the gut wall. The absorption step represents a key point in dairy peptide bioactivity at the target tissue.

Di- and tripeptides and AA from ingested proteins are easily absorbed by intestinal epithelial cells; however, 
Table 3. Major intestinal epithelial cell types and their role in the intestinal environment (Furness et al., 2013; Johansson et al., 2013; Peterson and Artis, 2014)

\begin{tabular}{lll}
\hline Major epithelial cells & Role in the gastrointestinal system & Gastrointestinal site \\
\hline Enterocytes/colonocytes & $\begin{array}{l}\text { Nutrient absorption } \\
\text { Production of AMPs- C-type lectin regenerating islet-derived }\end{array}$ & Villus \\
protein III $\gamma$ (REGIII $\gamma$ ) & Crypt undifferentiated/villus after \\
Goblet & $\begin{array}{l}\text { Secretion of mucins, trefoil factor (TFF) and resistin-like } \\
\text { molecule- } \beta \text { (RELM } \beta \text { ) }\end{array}$ & Crypt undifferentiated/villus after \\
Enteroendocrine & Digestion & differentiation \\
Paneth & Mucosal host defense/secretion of antimicrobial peptides (AMPs) & Crypt bottom \\
\hline
\end{tabular}

orally administered long-chain bioactive peptides may have complications in crossing the intestinal epithelial cell barrier and therefore lose the ability to act in vivo. Taking oral administration of ACE inhibitory peptides as an example, these peptides must remain intact and active after intestinal transport and contact with brush border peptidases. The in vivo ACE inhibitory effect of dairy proteins (Fekete et al., 2018), in fact, is mediated through receptors on the intestinal wall (MinerWilliams et al., 2014; Sangsawad et al., 2018).

In an in vitro study performed with Caco-2 cells, Satake et al. (2002) demonstrated that lactotripeptides are effectively transported across the epithelium via the paracellular route and showed activity both in vitro and in vivo. However, Vij et al. (2016) indicated that the major route of VLPVPQK casein peptide transport might be via the PepT1 transporter rather than via transcytosis or a paracellular route. Based on this, it is of paramount importance to elucidate the transport permeability and route of dairy peptides across the intestinal epithelium to correctly predict their bioactivity potential.

Among IEC, goblet cells are the second most abundant after enterocytes; they have a crucial role in producing the mucus layer which covers the intestinal mucosa. The mucus layer is an integral structural component of the intestinal barrier that acts as a medium for the protection and lubrication of the epithelium as well as transport between the luminal content and the epithelial lining (Deplancke and Gaskins, 2001). Several studies have been focused on the effect of dairy proteins in mucin production and mucus gene expression, and the beneficial role of dairy peptides have been intensively studied in mucus-producing goblet intestinal cell (Martínez-Maqueda et al., 2013a; Plaisancié et al., 2013). The mucus layer is maintained through a continuous secretion of mucins by goblet cells. Mucins consist of a core protein structure linked to numerous hygroscopic and hydrophilic oligosaccharide side-chains that contribute to the formation of a gel-like structure and can be divided into secreted and membrane-associ- ated mucins (Liévin-Le Moal and Servin, 2006; Lang et al., 2007; Figure 3).

The epithelial intestinal barrier is the first gate, which actively interacts with dairy proteins after ingestion, making the intestinal cells one of the first target tissues for the bioactive peptides. Intestinal cell-based models have been widely used in nutritional research as a predictive tool to study the absorption, mechanism of action, and different nutritional and bioactive effects of food compounds, including milk and dairy proteins, at the gastrointestinal level. Intestinal epithelial cells are strongly influenced by interactions with neighboring cells (e.g., immune cells); therefore, the co-cultivation of intestinal epithelial cells with immune cells allow investigation of the effects of bioactive proteins and peptides on intercellular communication. Intestinal or immune co-cultures, however, have not been used widely due to the lack of standardization in immune cells response,

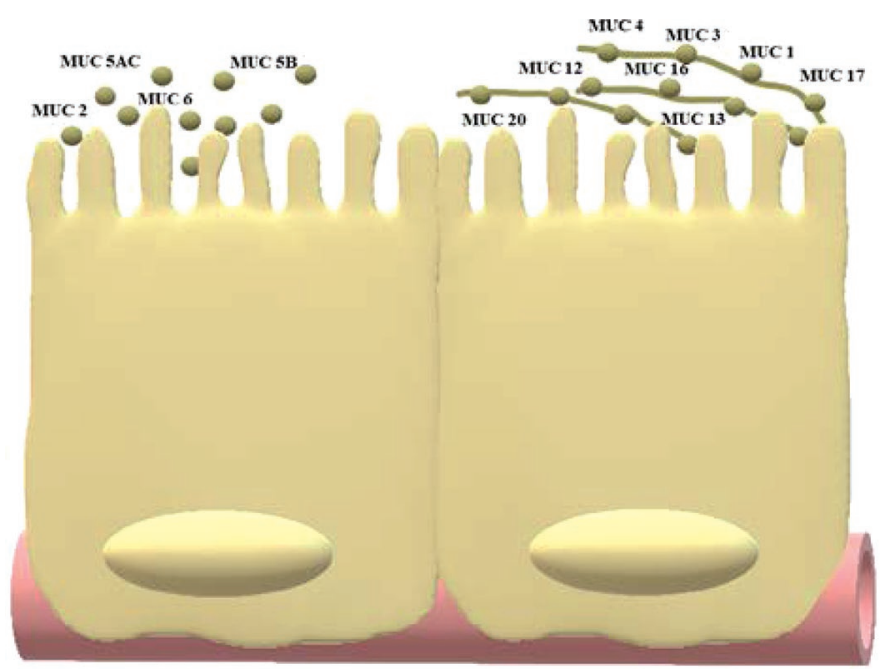

Figure 3. Graphical representation of membrane-bound glycoproteins adhered to the goblet epithelial wall (MUC1, MUC3, MUC4, MUC12, MUC13, MUC16, MUC17, and MUC20) and secreted in the mucus [MUC2 (most abundant in the small intestine), MUC5AC, MUC5B, and MUC6]. 
which depends on the donor and can lead to increased variability between experiments (Kleiveland, 2015).

The choice of the appropriate cell model is essential for the outcome when dairy bioactives are tested in cell culture (Purup and Nielsen, 2012). The cell model should be a compromise between easy handling and high human or animal predictive power, providing data that supports the interpretation of results for an in vivo situation. Primary cells are rarely used in nutritional research due to scarce reproducibility of the results and short life span. Indeed, primary cells survive only few days in cell culture, making the experimental reproducibility a major limit (Cencič and Langerholc, 2010; Langerholc et al., 2011). Among the cell lines available, Caco-2 cells have been widely used for absorptive, proliferative, and mechanistic studies; they express the characteristics and functionality of enterocytes upon reaching confluence (Langerholc et al., 2011). The human colon carcinoma HT-29 cells, besides being a model to study the different aspects of the biology of human cancer, received interest in food digestion and bioactivity studies. Goblet cells have the crucial role of secreting mucins (Goto and Kiyono, 2012) and can be mimicked in vitro using mucus-secreting cell line HT29-MTX-E12. The HT29-MTX-E12 cells were extensively used to study the role of bioactive dairy peptides in mucus production and gut functionality (Martínez-Maqueda et al., 2013b; Giromini et al., 2015). A summary of the major intestinal cell lines used to study dairy protein and peptide absorption and bioactivity is reported in Table 4 . The literature of in vitro dairy protein studies shows that the Caco-2 cell line is mainly used in absorption or transport studies, whereas the HT29-MTX cell line is mainly involved in mucus-modulation studies. Both IPEC-J2 and IPEC-I cell lines are good candidate models to study antibacterial peptides at the gastrointestinal level (Mariani et al., 2009; Brosnahan and Brown, 2012).

\section{COMBINED MODELS: IN VITRO DIGESTION CELL-BASED ASSAY}

In recent studies, the bioactive effects of dairy proteins have been assessed using the protocol reported by Petrat-Melin et al. (2017). Those authors studied the digestion fate of $\beta-\mathrm{CN}$ and the formation of bioactive peptides VYPFPGPIHN and VYPFPGPIPN using a pepsin and pancreatin protocol. Based on the digestion results, Petrat-Melin et al. (2017) synthesized the bioactive peptides in vitro and assessed their ACE inhibitory capacity before and after incubation with a monolayer of Caco-2 cells. The ACE inhibitory capacity in vivo can be mediated by the synergistic effect of a combination of peptides or by the whole protein digestate; therefore, the combination of in vitro digestion models with intestinal cell culture models may increase the physiological relevance of in vitro studies. To date, only a few studies have used combined models with dairy bioactive compounds. Picariello et al. (2013) applied a combined model to investigate the delivery of bioactive milk peptides across monolayers of intestinal Caco-2 cells. Furthermore, Giromini et al. (2016) used a combined in vitro digestion and cell culture model to study the proliferative effect of caseins and whey proteins at the intestinal level. Basiricò et al. (2015) studied the release of ACE inhibitor peptides during in vitro gastrointestinal digestion of Parmigiano Reggiano cheese and their absorption through an in vitro model of intestinal epithelium. Volstatova et al. (2016) combined the application of the INFOGEST protocol to study the effect of milk digesta from bovine, goats, and sheep on Lactobacillus adherence to human Caco2/HT29-MTX intestinal cells. Pepe et al. (2016) was the first to couple the in vitro digestion of Stracchino cheese to intestinal bioavailability and bioactivity studies. The digestate was fractionated by a semipreparative reverse-phase liquid chromatography and tested both for bioavailability and antioxidant properties in an $\mathrm{H}_{2} \mathrm{O}_{2}$-stressed Caco-2 cell line. The in vitro digestion, together with the intestinal cell absorption, can provide several pieces of information for in vivo correlations. However, the number of in vitro digestion or cell culture studies is limited, and the application of the combined models to study the physiology of dairy protein digestion and bioactive peptide evaluation is at its beginning. The application of the combined models, however, should always be a balanced compromise between biotechnological complexity and physiological relevance (Guerra et al., 2012). Obviously, other parameters should be carefully considered, including the presence of other food components, such as lipids and sugars, as well as the stability of the peptides, which are able to enter systemic circulation. A strict interaction among the gut epithelium, microbiota, and the secondary target tissues exists due to chemical and biological signals mediated by food compounds or their metabolites. The application of multiorgan cell culture models composed of a series of bioreactors simulating the dynamics of the different tissue environment in a single model was proposed by Ahluwalia et al. (2018). Each bioreactor contains a specific cell type and all bioreactors are interconnected by a continual flux of culture medium. These systems allow testing of translocation across epithelial barriers of a compound and the transport of absorbed nutrients to the blood stream circulation or secondary target organs. Even though these systems are in the early stages of development, further investigations should be focused on the development of 


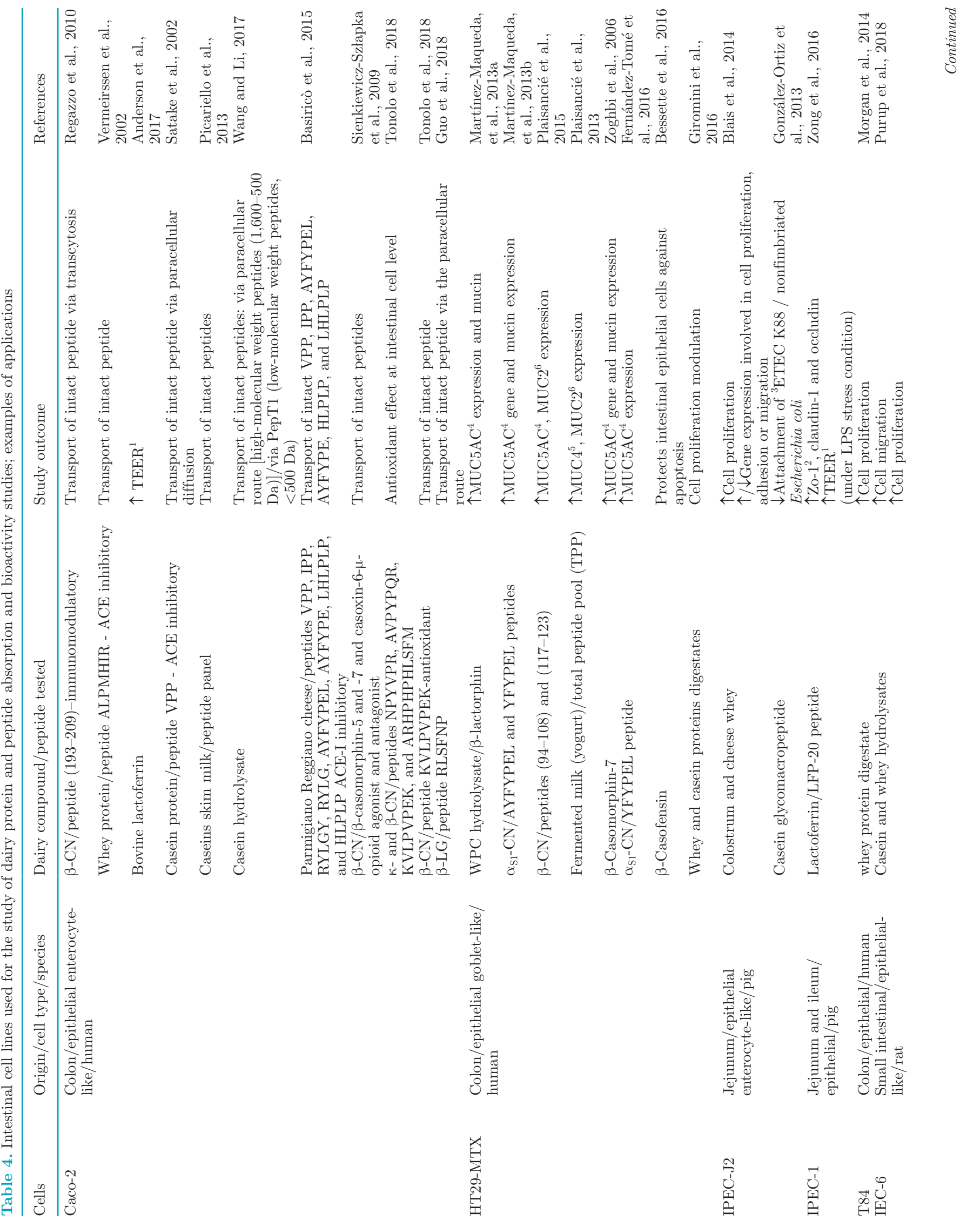




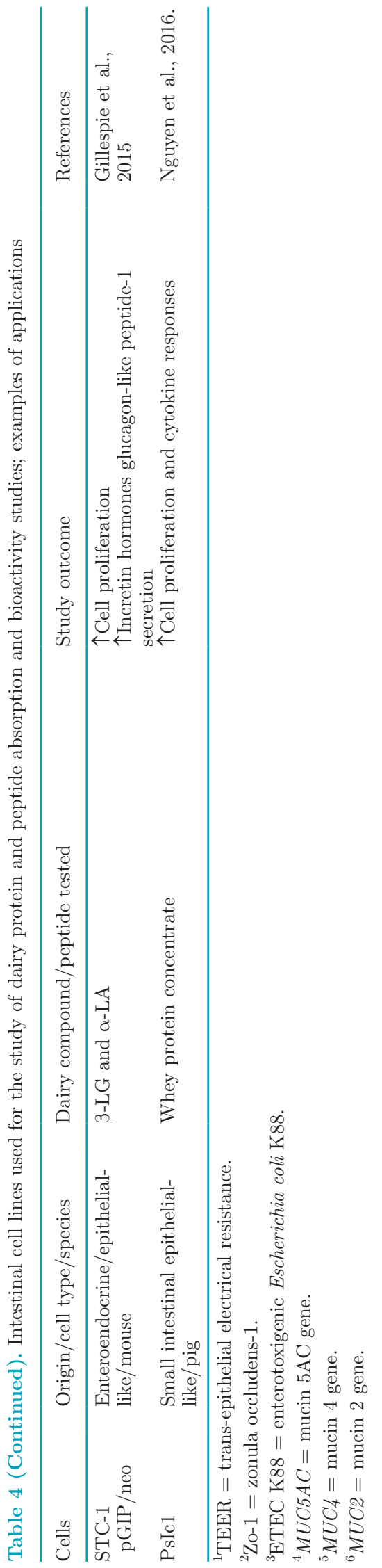

complex in vitro systems, which can be used before or in parallel to in vivo intervention studies.

\section{CONCLUSIONS}

The most important health benefits of dairy proteins are obtained following gastrointestinal digestion and peptide release. Static and dynamic digestion models that apply simulated human digestion conditions are becoming valuable tools for the estimation of preabsorptive events (i.e., digestibility, bioaccessibility) of dairy proteins and peptides. Further improvements could be made to make these systems even more relevant, such as coupling the digestion models with intestinal cell culture to simulate the epithelial transport and the intestinal bioactive properties of the dairy peptides and AA obtained as a digested mixture. Such an approach can overcome the major limitation of using synthetic peptides in cell-based bioassays. According to the principle of replacement, reduction, and refinement, the latter approach may limit the number of experimental animals used during in vivo trials and facilitate the study of the mechanism of action of specific proteins and peptides and the relative digestion metabolites. Dairy peptides primarily modulate the intestinal epithelium (bioaccessible fraction), but after intestinal absorption, they may influence the function and the physiology of other tissues and organs (bioavailable and bioactive fraction). In vitro digestion models in association with a cell-based bioassay provide an enormous boost to the practical and economic potential of dairy protein bioactivity measurements. The increasing sophistication of in vitro models has several advantages from ethical, economical, and scientific perspectives, even though it remains unavoidable to extend the results obtained in vitro to appropriate in vivo bioavailability assays to track the metabolic fate of dietary proteins and to validate the actual involvement of dairy peptides in physiological events.

\section{REFERENCES}

Ahluwalia, A., A. Misto, F. Vozzi, C. Magliaro, G. Mattei, M. C. Marescotti, A. Avogaro, and E. Iori. 2018. Systemic and vascular inflammation in an in vitro model of central obesity. PLoS One 13:e0192824. https://doi.org/10.1371/journal.pone.0192824.

Akalın, A. S. 2014. Dairy-derived antimicrobial peptides: Action mechanisms, pharmaceutical uses and production proposals. Trends Food Sci. Technol. 36:79-95. https://doi.org/10.1016/j.tifs.2014 .01 .002 .

Aluko, R. E. 2015. Antihypertensive peptides from food proteins. Annu. Rev. Food Sci. Technol. 6:235-262. https://doi.org/10 .1146/annurev-food-022814-015520.

Anderson, R. C., S. A. Bassegtt, N. W. Haggarty, P. K. Gopal, K. M. Armstrong, and N. C. Roy. 2017. Early-lactation, but not midlactation, bovine lactoferrin preparation increases epithelial barrier integrity of Caco-2 cell layers. J. Dairy Sci. 100:886-891. https: //doi.org/10.3168/jds.2016-11803. 
Asledottir, T., T. T. Le, B. Petrat-Melin, T. G. Devold, L. B. Larsen, and G. E. Vegarud. 2017. Identification of bioactive peptides and quantification of $\beta$-casomorphin-7 from bovine $\beta$-casein A1, A2 and I after ex vivo gastrointestinal digestion. Int. Dairy J. 71:98106. https://doi.org/10.1016/j.idairyj.2017.03.008.

Asledottir, T., T. T. Le, N. A. Poulsen, T. G. Devold, L. B. Larsen, and G. E. Vegarud. 2018. Release of $\beta$-casomorphin-7 from bovine milk of different $\beta$-casein variants after ex vivo gastrointestinal digestion. Int. Dairy J. 81:8-11. https://doi.org/10.1016/j.idairyj .2017.12.014.

Baldi, A., and L. Pinotti. 2008. Lipophilic microconstituents of milk. Pages 109-125 in Bioactive Components of Milk. Vol 606. Z. Bosze, ed. Springer, New York, NY.

Baldi, A., I. Politis, C. Pecorini, E. Fusi, R. Chronopoulou, and V. Dell'Orto. 2005. Biological effects of milk proteins and their peptides with emphasis on those related to the gastrointestinal ecosystem. J. Dairy Res. 72:66-72. https://doi.org/10.1017/ S002202990500110X.

Basiricò, L., E. Catalani, P. Morera, S. Cattaneo, M. Stuknyte, U. Bernabucci, I. De Noni, and A. Nardone. 2015. Release of angiotensin converting enzyme-inhibitor peptides during in vitro gastrointestinal digestion of Parmigiano Reggiano PDO cheese and their absorption through an in vitro model of intestinal epithelium. J. Dairy Sci. 98:7595-7601. https://doi.org/10.3168/jds.2015-9801.

Beltrán-Barrientos, L. M., A. Hernández-Mendoza, M. J. TorresLlanez, A. F. González-Córdova, and B. Vallejo-Córdoba. 2016. Invited review: Fermented milk as antihypertensive functional food. J. Dairy Sci. 99:4099-4110. https://doi.org/10.3168/jds.2015 -10054 .

Bessette, C., B. Benoit, S. Sekkal, J. Bruno, M. Estienne, J. Léonil, L. Ferrier, V. Théodorou, and P. Plaisancié. 2016. Protective effects of $\beta$-casofensin, a bioactive peptide from bovine beta-casein, against indomethacin-induced intestinal lesions in rats. Mol. Nutr. Food Res. 60:823-833. https://doi.org/10.1002/mnfr.201500680.

Bhat, Z. F., S. Kumar, and H. F. Bhat. 2017. Antihypertensive peptides of animal origin: A review. Crit. Rev. Food Sci. Nutr. 57:566578. https://doi.org/10.1080/10408398.2014.898241.

Blais, M., Y. Pouliot, S. Gauthier, Y. Boutin, and M. Lessard. 2014 A gene expression programme induced by bovine colostrum whey promotes growth and wound-healing processes in intestinal epithelial cells. J. Nutr. Sci. 3:e57. https://doi.org/10.1017/jns.2014.56.

Bohn, T., F. Carriere, L. Day, A. Deglaire, L. Egger, D. Freitas, M. Golding, S. Le Feunteun, A. Macierzanka, O. Menard, B. Miralles, A. Moscovici, R. Portmann, I. Recio, D. Rémond, V. Santé-Lhoutelier, T. J. Wooster, U. Lesmes, A. R. Mackie, and D. Dupont. 2017. Correlation between in vitro and in vivo data on food digestion. What can we predict with static in vitro digestion models? Crit. Rev. Food Sci. Nutr. 14:1-23. https://doi.org/10 $.1080 / 10408398.2017 .1315362$.

Boirie, Y., M. Dangin, P. Gachon, M. P. Vasson, J. L. Maubois, and B. Beaufrere. 1997. Slow and fast dietary proteins differently modulate postprandial protein accretion. Proc. Natl. Acad. Sci. USA 94:14930-14935. https://doi.org/10.1073/pnas.94.26.14930.

Boland, M., H. Singh, and A. Thompson. 2014. Milk Proteins: From Expression to food. Academic Press, San Diego, CA.

Boudry, G., M. K. Hamilton, M. Chichlowski, S. Wickramasinghe, D. Barile, K. M. Kalanetra, D. A. Mills, and H. E. Raybould. 2017. Bovine milk oligosaccharides decrease gut permeability and improve inflammation and microbial dysbiosis in diet-induced obese mice. J. Dairy Sci. 100:2471-2481. https://doi.org/10.3168/jds 2016-11890.

Boutrou, R., G. Henry, and L. Sanchez-Rivera. 2015. On the trail of milk bioactive peptides in human and animal intestinal tracts during digestion: A review. Dairy Sci. Technol. 95:815-829. https:// doi.org/10.1007/s13594-015-0210-0.

Brosnahan, A. J., and D. R. Brown. 2012. Porcine IPEC-J2 intestinal epithelial cells in microbiological investigations. Vet. Microbiol. 156:229-237. https://doi.org/10.1016/j.vetmic.2011.10.017.

Caroli, A., A. Poli, D. Ricotta, G. Banfi, and D. Cocchi. 2011. Invited review: Dairy intake and bone health: A viewpoint from the state of the art. J. Dairy Sci. 94:5249-5262. https://doi.org/10.3168/jds .2011-4578.

Cattaneo, S., M. Stuknytè, A. Ferraretto, and I. De Noni. 2017. Impact of the in vitro gastrointestinal digestion protocol on casein phosphopeptide profile of Grana Padano cheese digestates. Lebensm. Wiss. Technol. 77:356-361. https://doi.org/10.1016/j.lwt 2016.11.069.

Cencič, A., and T. Langerholc. 2010. Functional cell models of the gut and their applications in food microbiology. Int. J. Food Microbiol. 141:S4-14. https://doi.org/10.1016/j.ijfoodmicro.2010.03.026.

Cicero, A. F., F. Fogacci, and A. Colletti. 2017. Potential role of bioactive peptides in prevention and treatment of chronic diseases: A narrative review. Br. J. Pharmacol. 174:1378-1394. https://doi org/10.1111/bph.13608.

Contreras, M. D. M., B. Hernandez-Ledesma, L. Amigo, P. J. MartınAlvarez, and I. Recio. 2011. Production of antioxidant hydrolyzates from a whey protein concentrate with thermolysin: Optimization by response surface methodology. Lebensm. Wiss. Technol. 44:9-15. https://doi.org/10.1016/j.lwt.2010.06.017.

De Noni. I., M. Stuknyte, and S. Cattaneo. 2015. Identification of $\beta$-casomorphins 3 to 7 in cheeses and in their in vitro gastrointestinal digestates. Lebensm. Wiss. Technol. 63:550-555. https://doi .org/10.1016/j.lwt.2015.03.036.

de Oliveira, S. C., C. Bourlieu, O. Ménard, A. Bellanger, G. Henry, F. Rousseau, E. Dirson, F. Carrière, D. Dupont, and A. Deglaire. 2016a. Impact of pasteurization of human milk on preterm newborn in vitro digestion: Gastrointestinal disintegration, lipolysis and proteolysis. Food Chem. 211:171-179. https://doi.org/10 .1016/j.foodchem.2016.05.028.

de Oliveira, S. C., A. Deglaire, O. Ménard, A. Bellanger, F. Rousseau, G. Henry, E. Dirson, F. Carrière, D. Dupont, and C. Bourlieu. 2016b. Holder pasteurization impacts the proteolysis, lipolysis and disintegration of human milk under in vitro dynamic term newborn digestion. Food Res. Int. 88:263-275. https://doi.org/10 $.1016 /$ j.foodres.2015.11.022.

Deplancke, B., and H. R. Gaskins. 2001. Microbial modulation of innate defense: Goblet cells and the intestinal mucus layer. Am. J. Clin. Nutr. 73:1131S-1141S. https://doi.org/10.1093/ajcn/73.6 $.1131 \mathrm{~S}$

Douëllou, T., M. C. Montel, and D. T. Sergentet. 2017. Invited review: Anti-adhesive properties of bovine oligosaccharides and bovine milk fat globule membrane-associated glycoconjugates against bacterial food enteropathogens. J. Dairy Sci. 100:3348-3359. https: //doi.org/10.3168/jds.2016-11611.

Egger, L., and O. Ménard. 2017. Update on bioactive peptides after milk and cheese digestion. Curr. Opin. Food Sci. 14:116-121. https://doi.org/10.1016/j.cofs.2017.03.003.

Egger, L., O. Ménard, C. Baumann, D. Duerr, P. Schlegel, P. Stoll, G. Vergères, D. Dupont, and R. Portmann. 2017. Digestion of milk proteins: Comparing static and dynamic in vitro digestion systems with in vivo data. Food Res. Int. https://doi.org/10.1016/j.foodres .2017.12.049.

Egger, L., O. Ménard, C. Delgado-Andrade, P. Alvito, R. Assunção, S. Balance, R. Barberá, A. Brodkorb, T. Cattenoz, A. Clemente, I. Comi, D. Dupont, G. Garcia-Llatas, M. JesúsLagarda, S. Le Feunteun, L. JanssenDuijghuijsen, S. Karakaya, U. Lesmes, A. R. Mackie, C. Martins, A. Meynier, B. Miralles, B. S. Murray, A. Pihlanto, G. Picariello, C. N. Santos, S. Simsek, I. Recio, N. Rigby, L. Rioux, H. Stoffers, A. Tavares, L. Tavares, S. Turgeon, E. K. Ulleberg, G. E. Vegarud, G. Vergères, and R. Portmann. 2016. The harmonized INFOGEST in vitro digestion method: From knowledge to action. Food Res. Int. 88:217-225. https://doi.org/ 10.1016/j.foodres.2015.12.006.

Etcheverry, P., M. A. Grusak, and L. E. Fleige. 2012. Application of in vitro bioaccessibility and bioavailability methods for calcium, carotenoids, folate, iron, magnesium, polyphenols, zinc, and vitamins B6, B12, D, and E. Front. Physiol. 3:317. https://doi.org/10 .3389/fphys.2012.00317.

Fekete, A. A., C. Giromini, Y. Chatzidiakou, D. I. Givens, and J. A. Lovegrove. 2016a. Whey protein lowers blood pressure and im- 
proves endothelial function and lipid biomarkers in adults with prehypertension and mild hypertension: Results from the chronic Whey2Go randomized controlled trial. Am. J. Clin. Nutr. 104:1534-1544. https://doi.org/10.3945/ajcn.116.137919.

Fekete, Á. A., C. Giromini, Y. Chatzidiakou, D. I. Givens, and J. A. Lovegrove. 2018. Whey protein lowers systolic blood pressure and Ca-caseinate reduces serum TAG after a high-fat meal in mildly hypertensive adults. Sci. Rep. 8:5026. https://doi.org/10.1038/ s41598-018-23333-2.

Fekete, A. A., D. I. Givens, and J. A. Lovegrove. 2013. The impact of milk proteins and peptides on blood pressure and vascular function: a review of evidence from human intervention studies. Nutr. Res. Rev. 26:177-190. https://doi.org/10.1017/S0954422413000139.

Fekete, Á. A., D. I. Givens, and J. A. Lovegrove. 2015. Casein-derived lactotripeptides reduce systolic and diastolic blood pressure in a meta-analysis of randomised clinical trials. Nutrients 7:659-681. https://doi.org/10.3390/nu7010659.

Fekete, A. A., D. I. Givens, and J. A. Lovegrove. 2016b. Can milk proteins be a useful tool in the management of cardiometabolic health? An updated review of human intervention trials. Proc. Nutr. Soc. 75:328-341.

Fernández-Tomé, S., D. Martínez-Maqueda, R. Girón, C. Goicoechea, B. Miralles, and I. Recio. 2016. Novel peptides derived from as1casein with opioid activity and mucin stimulatory effect on HT29MTX cells. J. Funct. Foods 25:466-476. https://doi.org/10.1016/ j.jff.2016.06.023.

Fox, P. F., T. Uniacke-Lowe, P. L. H. McSweeney, and J. A. O'Mahony. 2015. Milk proteins. Pages 145-239 in Dairy Chemistry and Biochemistry. Springer International Publishing. https://doi.org/10 .1007/978-3-319-14892-2_4.

Furlund, C. B., E. K. Ulleberg, T. G. Devold, R. Flengsrud, M. Jacobsen, C. Sekse, H. Holm, and G. E. Vegarud. 2013. Identification of lactoferrin peptides generated by digestion with human gastrointestinal enzymes. J. Dairy Sci. 96:75-88. https://doi.org/10.3168/ jds.2012-5946.

Furness, J. B., L. R. Rivera, H. J. Cho, D. M. Bravo, and B. Callaghan. 2013. The gut as a sensory organ. Nat. Rev. Gastroenterol. Hepatol. 10:729-740.

Gerbe, F., C. Legraverend, and P. Jay. 2012. The intestinal epithelium tuft cells: Specification and function. Cell. Mol. Life Sci. 69:29072917.

Gillespie, A. L., D. Calderwood, L. Hobson, and B. D. Green. 2015. Whey proteins have beneficial effects on intestinal enteroendocrine cells stimulating cell growth and increasing the production and secretion of incretin hormones. Food Chem. 189:120-128. https:// doi.org/10.1016/j.foodchem.2015.02.022.

Giromini, C., A. Baldi, E. Fusi, R. Rebucci, and S. Purup. 2015. Effect of growth factors, estradiol 17- $\beta$, and short chain fatty acids on the intestinal HT29-MTX cells. Cell Biol. Toxicol. 31:199-209. https:/ /doi.org/10.1007/s10565-015-9304-y.

Giromini, C., Á. A. Fekete, D. I. Givens, A. Baldi, and J. A. Lovegrove. 2017. Short-communication: A comparison of the in vitro angiotensin-1-converting enzyme inhibitory capacity of dairy and plant protein supplements. Nutrients 9:1352. https://doi.org/10 $.3390 / \mathrm{nu} 9121352$.

Giromini, C., A. A. Fekete, J. A. Lovegrove, D. Givens, R. Rebucci, and A. Baldi. 2016. In vitro antioxidant, ACE-inhibitory and citomodulatory properties of whey and casein proteins. Page 360 in Annual Meeting of the European Association for Animal Production. Wageningen Academic Publishers, Wageningen, the Netherlands.

González-Ortiz, G., R. G. Hermes, R. Jimenez-Diaz, J. F. Perez, and S. M. Martin-Orue. 2013. Screening of extracts from natural feed ingredients for their ability to reduce enterotoxigenic Escherichia coli (ETEC) K88 adhesion to porcine intestinal epithelial cell-line IPEC-J2. Vet. Microbiol. 167:494-499.

Goto, Y., and H. Kiyono. 2012. Epithelial barrier: An interface for the cross-communication between gut flora and immune system. Immunol. Rev. 245:147-163. https://doi.org/10.1111/j.1600-065X .2011.01078.x.
Guerra, A., L. Etienne-Mesmin, V. Livrelli, S. Denis, S. BlanquetDiot, and M. Alric. 2012. Relevance and challenges in modeling human gastric and small intestinal digestion. Trends Biotechnol. 30:591-600. https://doi.org/10.1016/j.tibtech.2012.08.001.

Guo, Q., A. Ye, M. Lad, D. Dalgleish, and H. Singh. 2014. Effect of gel structure on the gastric digestion of whey protein emulsion gels. Soft Matter 10:1214-1223. https://doi.org/10.1039/c3sm52758a.

Guo, Y., J. Gan, Q. Zhu, X. Zeng, Y. Sun, Z. Wu, and D. Pan. 2018 Transepithelial transport of milk-derived angiotensin I-converting enzyme inhibitory peptide with the RLSFNP sequence. J. Sci. Food Agric. 98:976-983.

Haug, A., A. T. Høstmark, and O. M. Harstad. 2007. Bovine milk in human nutrition-a review. Lipids Health Dis. 6:25. https://doi .org/10.1186/1476-511X-6-25.

Hill, D. R., and D. S. Newburg. 2015. Clinical applications of bioactive milk components. Nutr. Rev. 73:463-476. https://doi.org/10.1093/ nutrit/nuv009.

Holt, C., J. A. Carver, H. Ecroyd, and D. C. Thorn. 2013. Invited review: Caseins and the casein micelle: their biological functions, structures, and behavior in foods. J. Dairy Sci. 96:6127-6146. https://doi.org/10.3168/jds.2013-6831.

Inglingstad, R. A., T. G. Devold, E. K. Eriksen, H. Holm, M. Jacobsen, K. H. Liland, E. O. Rukke, and G. E. Vegarud. 2010. Comparison of the digestion of caseins and whey proteins in equine, bovine, caprine and human milks by human gastrointestinal enzymes. Dairy Sci. Technol. 90:549-563. https://doi.org/10.1051/ dst/2010018.

Johansson, M. E., H. Sjövall, and G. C. Hansson. 2013. The gastrointestinal mucus system in health and disease. Nat. Rev. Gastroenterol. Hepatol. 10:352-361. https://doi.org/10.1038/nrgastro.2013 .35 .

Kamstrup, D., R. Berthelsen, P. J. Sassene, A. Selen, and A. Müllertz. 2017. In vitro model simulating gastro-intestinal digestion in the pediatric population (neonates and young infants). AAPS PharmSciTech 18:317-329. https://doi.org/10.1208/s12249-016-0649-1.

Kleiveland, C. R. 2015. Co-culture Caco-2/immune cells. Pages 197205 in The Impact of Food Bioactives on Health. Springer. https:/ /doi.org/https://doi.org/10.1007/978-3-319-16104-4_18.

Lang, T., G. C. Hansson, and T. Samuelsson. 2007. Gel-forming mucins appeared early in metazoan evolution. Proc. Natl. Acad. Sci. USA 104:16209-16214. https://doi.org/10.1073/pnas.0705984104.

Langerholc, T., P. A. Maragkoudakis, J. Wollgast, L. Gradisnik, and A. Cencic. 2011. Novel and established intestinal cell line models-An indispensable tool in food science and nutrition. Trends Food Sci. Technol. 22:S11-S20. https://doi.org/10.1016/j.tifs.2011 .03 .010 .

Liévin-Le Moal, V., and A. L. Servin. 2006. The front line of enteric host defense against unwelcome intrusion of harmful microorganisms: mucins, antimicrobial peptides, and microbiota. Clin. Microbiol. Rev. 19:315-337. https://doi.org/10.1128/CMR.19.2.315-337 .2006 .

Mariani, V., S. Palermo, S. Fiorentini, A. Lanubile, and E. Giuffra. 2009. Gene expression study of two widely used pig intestinal epithelial cell lines: IPEC-J2 and IPI-2I. Vet. Immunol. Immunopathol. 131:278-284. https://doi.org/10.1016/j.vetimm.2009.04 .006 .

Martínez-Augustin, O., B. Rivero-Gutiérrez, C. Mascaraque, and F. Sánchez de Medina. 2014. Food derived bioactive peptides and intestinal barrier function. Int. J. Mol. Sci. 15:22857-22873. https: //doi.org/10.3390/ijms151222857.

Martínez-Maqueda, D., B. Miralles, I. Recio, and B. Hernández-Ledesma. 2012b. Antihypertensive peptides from food proteins: A review. Food Funct. 3:350-361. https://doi.org/10.1039/C2FO10192K.

Martínez-Maqueda, D., B. Miralles, E. Cruz-Huerta, and I. Recio. 2013b. Casein hydrolysate and derived peptides stimulate mucin secretion and gene expression in human intestinal cells. Int. Dairy J. 32:13-19. https://doi.org/10.1016/j.idairyj.2013.03.010.

Martínez-Maqueda, D., B. Miralles, S. De Pascual-Teresa, I. Reverón, R. Muñoz, and I. Recio. 2012a. Food-derived peptides stimulate mucin secretion and gene expression in intestinal cells. J. Agric Food Chem. 60:8600-8605. https://doi.org/10.1021/jf301279k. 
Martínez-Maqueda, D., B. Miralles, M. Ramos, and I. Recio. 2013a. Effect of $\beta$-lactoglobulin hydrolysate and $\beta$-lactorphin on intestinal mucin secretion and gene expression in human goblet cells. Food Res. Int. 54:1287-1291. https://doi.org/10.1016/j.foodres.2012.12 .029 .

Mat, D. J., S. Le Feunteun, C. Michon, and I. Souchon. 2016. In vitro digestion of foods using $\mathrm{pH}$-stat and the INFOGEST protocol: Impact of matrix structure on digestion kinetics of macronutrients, proteins and lipids. Food Res. Int. 88:226-233. https://doi.org/10 .1016/j.foodres.2015.12.002.

Meddah, A. T., A. Yazourh, I. Desmet, B. Risbourg, W. Verstraete, and M. B. Romond. 2001. The regulatory effects of whey retentate from bifidobacteria fermented milk on the microbiota of the Simulator of the Human Intestinal Microbial Ecosystem (SHIME). J. Appl. Microbiol. 91:1110-1117. https://doi.org/10.1046/j.1365 $-2672.2001 .01482 . \mathrm{x}$

Meisel, H., and R. J. FitzGerald. 2003. Biofunctional peptides from milk proteins: Mineral binding and cytomodulatory effects. Curr. Pharm. Des. 9:1289-1295. https://doi.org/10.2174/ 1381612033454847.

Ménard, O., D. Picque, and D. Dupont. 2015. The DIDGI system. Pages 73-80 in The Impact of Food Bioactives on Health. K. Verhoeckx, P. Cotter, I. López-Expósito, C. Kleiveland, T. Lea, A. Mackie, T. Requena, D. Swiatecka, and H. Wichers, ed. Springer, Cham, Switzerland.

Minekus, M., M. Alminger, P. Alvito, S. Ballance, T. Bohn, C. Bourlieu, F. Carrière, R. Boutrou, M. Corredig, D. Dupont, C. Dufour, L. Egger, M. Golding, S. Karakaya, B. Kirkhus, S. Le Feunteun, U. Lesmes, A. Macierzanka, A. Mackie, S. Marze, D. J. McClements, O. Ménard, I. Recio, C. N. Santos, R. P. Singh, G. E. Vegarud, M. S. J. Wickham, W. Weitschies, and A. Brodkorb. 2014. A standardised static in vitro digestion method suitable for food-An international consensus. Food Funct. 5:1113-1124. https://doi.org/ $10.1039 / \mathrm{c} 3 f \circ 60702 \mathrm{j}$.

Miner-Williams, W. M., B. R. Stevens, and P. J. Moughan. 2014. Are intact peptides absorbed from the healthy gut in the adult human? Nutr. Res. Rev. 27:308-329. https://doi.org/10.1017/ S0954422414000225.

Miralles, B., R. del Barrio, C. Cueva, I. Recio, and L. Amigo. 2018b. Dynamic gastric digestion of a commercial whey protein concentrate. J. Sci. Food Agric. 98:1873-1879. https://doi.org/10.1002/ jsfa. 8668 .

Miralles, B., B. Hernández-Ledesma, S. Fernández-Tomé, L. Amigo, and I. Recio. 2018a. Health-related functional value of dairy proteins and peptides. Pages 523-568 in Proteins in Food Processing, 2nd ed. Woodhead Publishing Series in Food Science, Technology and Nutrition. https://doi.org/10.1016/B978-0-08-100722-8.00021 -8 .

Morgan, A. J., L. G. Riley, P. A. Sheehy, and P. C. Wynn. 2014. The influence of protein fractions from bovine colostrum digested in vivo and in vitro on human intestinal epithelial cell proliferation. J. Dairy Res. 81:73-81. https://doi.org/10.1017/S0022029913000654.

Nabil, S., S. F. Gauthier, R. Drouin, P. E. Poubelle, and Y. Pouliot. 2011. In vitro digestion of proteins and growth factors in a bovine whey protein extract as determined using a computer-controlled dynamic gastrointestinal system (TIM-1). Food Dig. 2:13-22. https://doi.org/10.1007/s13228-011-0010-9.

Nguyen, D. N., P. T. Sangild, Y. Li, S. B. Bering, and D. E. Chatterton. 2016. Processing of whey modulates proliferative and immune functions in intestinal epithelial cells. J. Dairy Sci. 99:959-969. https://doi.org/10.3168/jds.2015-9965.

Nik, A. M., A. J. Wright, and M. Corredig. 2010. Surface adsorption alters the susceptibility of whey proteins to pepsin-digestion. J. Colloid Interface Sci. 344:372-381. https://doi.org/10.1016/j.jcis 2010.01.006

Nongonierma, A. B., and R. J. FitzGerald. 2015. The scientific evidence for the role of milk protein-derived bioactive peptides in humans: A review. J. Funct. Foods 17:640-656. https://doi.org/10 $.1016 /$ j.jff.2015.06.021

Nongonierma, A. B., and R. J. FitzGerald. 2016. Strategies for the discovery, identification and validation of milk protein-derived bio- active peptides. Trends Food Sci. Technol. 50:26-43. https://doi .org/10.1016/j.tifs.2016.01.022.

Parada, J., and J. M. Aguilera. 2007. Food microstructure affects the bioavailability of several nutrients. J. Food Sci. 72:R21-R32. https: //doi.org/10.1111/j.1750-3841.2007.00274.x.

Pepe, G., E. Sommella, G. Ventre, M. C. Scala, S. Adesso, C. Ostacolo, S. Marzocco, E. Novellino, and P. Campiglia. 2016. Antioxidant peptides released from gastrointestinal digestion of "Stracchino" soft cheese: Characterization, in vitro intestinal protection and bioavailability. J. Funct. Foods 26:494-505. https://doi.org/10 .1016/j.jff.2016.08.021.

Peterson, L. W., and D. Artis. 2014. Intestinal epithelial cells: Regulators of barrier function and immune homeostasis. Nat. Rev. Immunol. 14:141-153. https://doi.org/10.1038/nri3608.

Petrat-Melin, B., P. Andersen, J. T. Rasmussen, N. A. Poulsen, L. B. Larsen, and J. F. Young. 2015. In vitro digestion of purified $\beta$-casein variants A 1, A 2, B, and I: Effects on antioxidant and angiotensin-converting enzyme inhibitory capacity. J. Dairy Sci. 98:15-26. https://doi.org/10.3168/jds.2014-8330.

Petrat-Melin, B., T. T. Le, H. S. Møller, L. B. Larsen, and J. F. Young. 2017. Inhibition of angiotensin 1-converting enzyme by peptides derived from variants of bovine $\beta$-casein upon apical exposure to a Caco-2 cell monolayer. J. Dairy Sci. 100:881-885. https://doi.org/ 10.3168/jds.2016-11684.

Picariello, G., G. Iacomino, G. Mamone, P. Ferranti, O. Fierro, C. Gianfrani, A. Di Luccia, and F. Addeo. 2013. Transport across Caco-2 monolayers of peptides arising from in vitro digestion of bovine milk proteins. Food Chem. 139:203-212. https://doi.org/10 .1016/j.foodchem.2013.01.063.

Plaisancié, P., R. Boutrou, M. Estienne, G. Henry, J. Jardin, A. Paquet, and J. Léonil. 2015. ß-Casein (94-123)-derived peptides differently modulate production of mucins in intestinal goblet cells. J. Dairy Res. 82:36-46. https://doi.org/10.1017/S0022029914000533.

Plaisancié, P., J. Claustre, M. Estienne, G. Henry, R. Boutrou, A. Paquet, and J. Léonil. 2013. A novel bioactive peptide from yoghurts modulates expression of the gel-forming MUC2 mucin as well as population of goblet cells and Paneth cells along the small intestine. J. Nutr. Biochem. 24:213-221. https://doi.org/10.1016/ j.jnutbio.2012.05.004

Politis, I. and R. Chronopoulou. 2008. Milk peptides and immune response in the neonate. Pages 253-269 in Bioactive Components of Milk Springer, New York, NY. https://doi.org/10.1007/978-0 $-387-74087-4 \_10$.

Purup, S., S. D. Nielsen, T. T. Le, H. Bertelsen, J. Sørensen, and L. B. Larsen. 2018. Wound healing properties of commercial milk hydrolysates in intestinal cells. Vet. Immunol. Immunopathol. https: //doi.org/10.1007/s10989-018-9692-y.

Purup, S., and T. S. Nielsen. 2012. Cell-based models to test the effects of milk-derived bioactives. Animal 6:423-432. https://doi .org/10.1017/S1751731111002540.

Regazzo, D., D. Mollé, G. Gabai, D. Tomé, D. Dupont, J. Leonil, and R. Boutrou. 2010. The (193-209) 17-residues peptide of bovine $\beta$-casein is transported through Caco- 2 monolayer. Mol. Nutr. Food Res. 54:1428-1435. https://doi.org/10.1002/mnfr.200900443.

Robert, H., D. Payros, P. Pinton, V. Théodorou, M. Mercier-Bonin, and I. P. Oswald. 2017. Impact of mycotoxins on the intestine: are mucus and microbiota new targets? J. Toxicol. Environ. Health B Crit. Rev. 20:249-275. https://doi.org/10.1080/10937404.2017 .1326071 .

Rosetta, L., and A. Baldi. 2008. On the role of breastfeeding in health promotion and the prevention of allergic diseases. Pages 467-483 in Bioactive components of milk. Vol 606. Z. Bosze, ed. Springer, New York, NY.

Sánchez-Rivera, L., O. Ménard, I. Recio, and D. Dupont. 2015. Peptide mapping during dynamic gastric digestion of heated and unheated skimmed milk powder. Food Res. Int. 77:132-139. https:// doi.org/10.1016/j.foodres.2015.08.001

Sanchón, J., S. Fernández-Tomé, B. Miralles, B. Hernández-Ledesma, D. Tomé, C. Gaudichon, and I. Recio. 2018. Protein degradation and peptide release from milk proteins in human jejunum. 
Comparison with in vitro gastrointestinal simulation. Food Chem. 239:486-494. https://doi.org/10.1016/j.foodchem.2017.06.134.

Sangsawad, P., K. Choowongkomon, D. D. Kitts, X. M. Chen, E. C. Li-Chan, and J. Yongsawatdigul. 2018. Transepithelial transport and structural changes of chicken angiotensin I-converting enzyme (ACE) inhibitory peptides through Caco-2 cell monolayers. J. Funct. Foods 45:401-408. https://doi.org/10.1016/j.jff.2018.04 .020 .

Santiago-López, L., A. Hernández-Mendoza, B. Vallejo-Cordoba, V. Mata-Haro, and A. F. González-Córdova. 2016. Food-derived immunomodulatory peptides. J. Sci. Food Agric. 96:3631-3641. https://doi.org/10.1002/jsfa.7697.

Satake, M., M. Enjoh, Y. Nakamura, T. Takano, Y. Kawamura, S. Arai, and M. Shimizu. 2002. Transepithelial transport of the bioactive tripeptide, Val-Pro-Pro, in human intestinal Caco-2 cell monolayers. Biosci. Biotechnol. Biochem. 66:378-384. https://doi .org/10.1271/bbb.66.378.

Shani-Levi, C., P. Alvito, A. Andres, R. Assunção, R. Barbera, S. BlanquetDiot, C. Bourlieu, A. Brodkorb, A. Cilla, A. Deglaire, S. Denis, D. Dupont, A. Heredia, S. Karakaya, C. V. L. Giosafatto, L. Mariniello, C. Martins, O. Menard, S. Nehir El, G. E. Vegarud, E. Ulleberg, and U. Lesmes. 2017. Extending in vitro digestion models to specific human populations: Perspectives, practical tools and bio-relevant information. Trends Food Sci. Technol. 60:52-63. https://doi.org/10.1016/j.tifs.2016.10.017.

Shimizu, M. 2004. Food-derived peptides and intestinal functions. Biofactors 21:43-47. https://doi.org/10.1002/biof.552210109.

Sienkiewicz-Szłapka, E., B. Jarmołowska, S. Krawczuk, E. Kostyra, H. Kostyra, and K. Bielikowiczsd. 2009. Transport of bovine milkderived opioid peptides across a Caco-2 monolayer. Int. Dairy J. 19:252-257. https://doi.org/10.1016/j.idairyj.2008.10.007.

Smithers, G. W. 2015. Whey-ing up the options-Yesterday, today and tomorrow. Int. Dairy J. 48:2-14. https://doi.org/10.1016/j .idairyj.2015.01.011.

Sultan, S., N. Huma, M. S. Butt, M. Aleem, and M. Abbas. 2018. Therapeutic potential of dairy bioactive peptides: A contemporary perspective. Crit. Rev. Food Sci. Nutr. 58:105-115. https:// doi.org/10.1080/10408398.2015.1136590.

Thuenemann, E. C., G. Mandalari, G. T. Rich and R.M. Faulks. 2015. Dynamic gastric model (DGM). Pages 47-59 in The Impact of
Food Bioactives on Health. Springer International Publishing. https://doi.org/10.1007/978-3-319-16104-4_6.

Tonolo, F., M. Sandre, S. Ferro, A. Folda, V. Scalcon, G. Scutari, E. Feller, O. Marin, A. Bindoli, and M. P. Rigobello. 2018. Milk-derived bioactive peptides protect against oxidative stress in a Caco2 cell model. Food Funct. https://doi.org/10.1039/c7fo01646h.

Vermeirssen, V., B. Deplancke, K. A. Tappenden, J. V. Camp, H. R Gaskins, and W. Verstraete. 2002. Intestinal transport of the lactokinin Ala-Leu-Pro-Met-His-Ile-Arg through a Caco-2 Bbe monolayer. J. Pept. Sci. 8:95-100. https://doi.org/10.1002/psc.371.

Vij, R., S. Reddi, S. Kapila, and R. Kapila. 2016. Transepithelial transport of milk derived bioactive peptide VLPVPQK. Food Chem. 190:681-688. https://doi.org/10.1016/j.foodchem.2015.05.121.

Visioli, F., and A. Strata. 2014. Milk, dairy products, and their functional effects in humans: A narrative review of recent evidence. Adv. Nutr. 5:131-143. https://doi.org/10.3945/an.113.005025.

Volstatova, T., J. Havlik, M. Potuckova, and M. Geigerova. 2016. Milk digesta and milk protein fractions influence the adherence of Lactobacillus gasseri $\mathrm{R}$ and Lactobacillus casei FMP to human cultured cells. Food Funct. 7:3531-3538. https://doi.org/10.1039/ c6fo00545d.

Wang, B., and B. Li. 2017. Effect of molecular weight on the transepithelial transport and peptidase degradation of casein-derived peptides by using Caco-2 cell model. Food Chem. 218:1-8. https:/ /doi.org/10.1016/j.foodchem.2016.08.106.

Zhang, Q., J. K. Cundiff, S. D. Maria, R. J. McMahon, M. S. J. Wickham, R. M. Faulks, and E. A. F. van Tol. 2014. Differential digestion of human milk proteins in a simulated stomach model. J. Proteome Res. 13:1055-1064. https://doi.org/10.1021/pr401051u.

Zoghbi, S., A. Trompette, J. Claustre, M. E. Homsi, J. Garzón, G. Jourdan, J. Y. Scoazec, and P. Plaisancié. 2006. $\beta$-Casomorphin-7 regulates the secretion and expression of gastrointestinal mucins through a $\mu$-opioid pathway. Am. J. Physiol. Gastrointest. Liver Physiol. 290:G1105-G1113. https://doi.org/10.1152/ajpgi.00455 .2005 .

Zong, X., W. Hu, D. Song, Z. Li, H. Du, Z. Lu, and Y. Wang. 2016. Porcine lactoferrin-derived peptide LFP-20 protects intestinal barrier by maintaining tight junction complex and modulating inflammatory response. Biochem. Pharmacol. 104:74-82. https://doi .org/10.1016/j.bcp.2016.01.009. 